\title{
GMR
}

\section{Comparison of eight methods to isolate genomic DNA from Hancornia speciosa}

\author{
V.M. Almeida ${ }^{1}$, G.A. Luz ${ }^{2}$, P.P. Martins ${ }^{2}$, M.F.C. Gomes ${ }^{2}$, M.F. Costa ${ }^{3}$, \\ P.S.C. Lima ${ }^{4}$ and S.E.S. Valente ${ }^{1}$ \\ ${ }^{1}$ Departamento de Biologia, Universidade Federal do Piauí, \\ Campus Ininga, Teresina, PI, Brasil \\ ${ }^{2}$ Programa de Pós-Graduação em Genética e Melhoramento, \\ Universidade Federal do Piauí, Centro de Ciências Agrárias, \\ Teresina, PI, Brasil \\ ${ }^{3}$ Campus Amílcar Ferreira Sobral, Universidade Federal do Piauí, \\ Floriano, PI, Brasil \\ ${ }^{4}$ Empresa Brasileira de Pesquisa Agropecuária, EMBRAPA Meio-Norte, \\ Teresina, PI, Brasil \\ Corresponding author: S.E.S. Valente \\ E-mail: svalente@ufpi.edu.br
}

Genet. Mol. Res. 16 (3): gmr16039724

Received May 15, 2017

Accepted July 10, 2017

Published July 28, 2017

DOI http://dx.doi.org/10.4238/gmr16039724

Copyright (C) 2017 The Authors. This is an open-access article distributed under the terms of the Creative Commons Attribution ShareAlike (CC BY-SA) 4.0 License.

ABSTRACT. Mangabeira (Hancornia speciosa) is a native fruit tree
found mainly in the Cerrado biome and shows great economic potential
due to its multiple uses; the fruits are used in agriculture, are important
as a food resource, and can be consumed in natura or processed. Due
to a reduction in the area of ecosystems where it occurs, mangabeira
is threatened by genetic erosion in Brazil. The characterization of
the genetic diversity of plants can provide the basis for strategies to
protect and conserve endangered populations, like mangabeira. This
study aimed to compare eight DNA extraction methods in mangabeira
because the key to success is the use of a pure genomic DNA for the
characterization of genetic diversity in molecular biology techniques.
The quality and concentration of DNA were revealed by agarose

Genetics and Molecular Research 16 (3): gmr16039724 
gel electrophoresis. Polymerase chain reaction amplifications were successfully by extractions using two commercial purification kits and by the method proposed by Khanuja et al. (1999), which produced sufficient genomic DNA of good quality from leaves of $H$. speciosa to perform techniques involving molecular biology. The protocol described by Khanuja et al. (1999) is less expensive when compared to the commercial purification kits.

Key words: DNA isolation; Mangabeira; Polymerase chain reaction

\section{INTRODUCTION}

The mangabeira (Hancornia speciosa Gomes) produces the latex that was extremely explored during the Second World War for the production of rubber (Oliveira, 2011). The latex of this species can be used in the treatment of gastritis and has anti-inflammatory property and antihypertensive effect (Marinho et al., 2011; Almeida et al., 2014).

The mangabeira is a medium-sized tree ( 4 to $7 \mathrm{~m}$ high), can reach up to $15 \mathrm{~m}$, and has slow growth and wide canopy. The stem is rough and may have 2 to 3 bifurcations, 0.2 to $0.3 \mathrm{~m}$ in diameter. The flowers are white, perfumed, hermaphrodite, and the inflorescence is composed of up to five bellflower-shaped flowers, and isolated flowers may also occur (Soares et al., 2015).

The mangabeira has six botanical varieties that differ, mainly, in the morphological characteristics related to the flower and leaf: $H$. speciosa var. cuyabenses, $H$. speciosa var. gardneri, $H$. speciosa var. lundii, $H$. speciosa var. maximiliani, $H$. speciosa var. pubescens, and $H$. speciosa var. speciosa. All varieties predominate in the Midwest and Southeast regions, except H. speciosa var. speciosa that is abundant in the Northeast and North regions of Brazil (Lédo et al., 2015).

Mangaba is a tropical fruit tree native to Brazil found in the main biomes of Brazil such as Caatinga, Cerrado, and Atlantic Forest (Campos Filho and Sartorelli, 2015). It belongs to the class Dicotyledoneae, order Gentinales, family Apocynaceae (Capinan, 2007; Nogueira et al., 2015).

This plant stands out for the economic potential of its fruits, which are appreciated mainly by the consumers of the Northeast and Midwest of Brazil, for its pleasant taste, high nutritional value, and excellent source of Vitamin A, Vitamin C, protein, phosphorus, and calcium (Soares et al., 2015).

The fruits can be consumed in natura or processed, in the form of candies, liqueurs, juices, and ice creams, which have stimulated the interest of the consumers and agroindustries (Ganga et al., 2010). The extract obtained from the leaves can have a hypotensive effect (Ferreira et al., 2007; Silva et al., 2011).

Although of economic potential, the exploitation of mangabeira is mainly carried out in an extractive way (Soares et al., 2015). Many natural populations of this species are in the process of genetic erosion that could reduce variability due to genetic bottleneck effects (Jimenez et al., 2015; Nogueira et al., 2015). Thus, it is important the development of conservation strategies to maintain the genetic diversity of this species; the knowledge of the genetic structure of natural populations of mangabeira is essential for their domestication and the genetic improvement (Ganga et al., 2010; Nogueira et al., 2015).

Genetics and Molecular Research 16 (3): gmr16039724 
One of the ways to evaluate the genetic diversity within and among populations is by molecular markers, which are not influenced by environmental conditions and do not present pleiotropic effect (Costa et al., 2011).

Genetic studies by molecular markers require appropriate DNA quality and quantity. However, obtaining pure DNA samples is a difficult process because the biochemical composition among plant species can be different. For this reason, several protocols have been developed and adapted to the current variation of the biochemical composition of plant tissues (Sousa et al., 2014; Viana et al., 2015). A good protocol should be simple, rapid, and efficient, providing adequate amounts of high-quality DNA suitable for molecular analysis.

Due to the need to obtain a high concentration of pure DNA for studies in molecular biology, the present study aimed to evaluate and optimize eight DNA extraction protocols and select the best protocol with the lower cost to mangabeira.

\section{MATERIAL AND METHODS}

Young leaf tissues free from ectoparasites and epibiotic organisms were collected from individuals maintained at the Germplasm Bank of Embrapa Meio-Norte, located in Teresina, Piauí, Brazil. The leaves were wrapped in paper towels, kept in plastic bags, placed in Styrofoam boxes with ice or were kept in hermetically sealed plastic bags containing silica for $24 \mathrm{~h}$.

Eight DNA extraction methods were tested from fresh and dehydrated leaves: six organic methods [Dellaporta et al. (1983), Doyle and Doyle (1987), Ferreira and Grattapaglia (1998), Khanuja et al. (1999), Murray and Thompson (1980), Romano and Brasileiro (1999)] and two commercial DNA extraction kits by the affinity membrane method [kit 1 (Qiagen, Venlo, Netherlands) and kit 2 (Invisorb Spin Plant Mini Kit, Invitek, Berlin, Germany)].

Genomic DNA was extracted as outlined in the instructions provided by the authors and manufacturers, except modifications to adapt to the amount of leaf tissue used. In each sample, the DNA was isolated from $20 \mathrm{mg}$ dehydrated leaves and $100 \mathrm{mg}$ fresh leaves by kit 1 and kit 2; and from $200 \mathrm{mg}$ young (dehydrated and fresh) leaves by organic methods. Leaf maceration was performed in two ways: liquid nitrogen in organic extraction methods and using a Precellys (France) homogenizer at $6600 \mathrm{rpm}$ for 2 cycles of $20 \mathrm{~s}$ in the affinity membrane methods. After the extraction, all the samples were diluted in $100 \mu \mathrm{L}$ TE buffer (1 mM EDTA, $10 \mathrm{mM}$ Tris-HCl, $\mathrm{pH} 8.0$ ). Reagents and their concentrations, specific to each extraction, were prepared as described in the respective protocols.

The integrity of extracted DNA was checked by electrophoresis on $0.8 \%$ agarose gel in Tris-borate-EDTA ( $0.5 \mathrm{X}$ TBE) buffer, at $80 \mathrm{~V}$ for $1.5 \mathrm{~h}$. The gels were stained with GelRed ${ }^{\mathrm{TM}}$ (1:1000; Biotium, Hayward, CA, USA), visualized under ultraviolet light and photographed. The quantity of extracted DNA was determined by comparing with $\lambda$ DNA standards $(20 \mathrm{ng} / \mu \mathrm{L})$. Electrophoresis on agarose gels was performed with the DNA samples obtained by all protocols and the two forms of storage of the leaves, in Styrofoam with ice (fresh leaves) or on silica gel (dehydrated leaves) aiming to select the best samples based on DNA integrity and quantity.

Polymerase chain reaction (PCR) amplifications were performed in a Veriti 96-Well Thermal Cycler (Applied Biosystems ${ }^{\circledR}$, USA) with an initial denaturation step of $1.5 \mathrm{~min}$ at $94^{\circ} \mathrm{C}$; 40 cycles of $40 \mathrm{~s}$ at $94^{\circ} \mathrm{C}, 45 \mathrm{~s}$ at $55^{\circ} \mathrm{C}, 2 \mathrm{~min}$ at $72^{\circ} \mathrm{C}$; and a final extension of $7 \mathrm{~min}$ at $72^{\circ} \mathrm{C}$. The inter-simple sequence repeat (ISSR) primer UBC857 (5'-ACA CAC ACA CAC ACA CYG-3') was obtained from University of British Columbia, Canada. The reaction mix contained $1 \mu \mathrm{L}$ DNA (7 ng/ $\mu \mathrm{L})$, buffer [20 mM Tris-HCl, $\mathrm{pH} 8.4,50 \mathrm{mM} \mathrm{KCl}], 1.5 \mathrm{mM}$

Genetics and Molecular Research 16 (3): gmr16039724 
$\mathrm{MgCl}_{2}, 1 \mathrm{mM}$ dNTP, $0.4 \mu \mathrm{M}$ primer, $0.5 \mathrm{U}$ Taq DNA polymerase, and ultrapure $\mathrm{H}_{2} \mathrm{O}$ in a 10$\mu \mathrm{L}$ final volume.

Another PCR was also performed using random amplification of polymorphic DNA (RAPD) primers: UBC549 (5'-CCGGCTTATG-3'), UBC556 (5'-ATGGATGACG-3'), and D-20 (5'-ACCCGGTCAC-3'). The reactions, in a 20- $\mu$ L final volume, contained 15 ng DNA, $0.25 \mathrm{mM}$ dNTPs, $1 \mathrm{U}$ Taq DNA polymerase, $0.2 \mathrm{mM}$ primer, $3.0 \mathrm{mM} \mathrm{MgCl}, 2.0 \mu \mathrm{L} 1 \mathrm{X}$ buffer, and ultrapure $\mathrm{H}_{2} \mathrm{O}$. The amplifications were performed in the Veriti 96-Well Thermal Cycler with an initial denaturation step of 5 min at $94^{\circ} \mathrm{C} ; 35$ cycles of $40 \mathrm{~s}$ at $94^{\circ} \mathrm{C}$ (denaturation), 1 min at $33^{\circ} \mathrm{C}$ (primer annealing), 2 min at $72^{\circ} \mathrm{C}$; and a final extension of $10 \mathrm{~min}$ at $72^{\circ} \mathrm{C}$.

The amplification products were separated on a $1.5 \%$ agarose gel in $0.5 \mathrm{X}$ TBE buffer, and the gels were stained with GelRed ${ }^{\mathrm{TM}}$ (1:1000). The sizes of the amplified fragments were determined based on 1-kb DNA ladder (Invitrogen, Life Technologies do Brazil, São Paulo, SP, Brazil), and the products were visualized under ultraviolet light and documented.

\section{RESULTS AND DISCUSSION}

The protocols published by Ferreira and Grattapaglia (1998), Doyle and Doyle (1987), Murray and Thompson (1980), Dellaporta et al. (1983), and Romano and Brasileiro were not efficient in the DNA extraction of mangabeira. The two commercial DNA extraction kits (kit 1 and kit 2), from dehydrated leaves, and the DNA extraction kit 1 from fresh leaves, isolated a pure DNA that showed a high concentration. The quantification of samples relative to the method described by Khanuja et al. (1999) extracted from leaves stored in a plastic bag containing silica gel confirmed the isolation of intact and high-quality DNA (Figure 1).

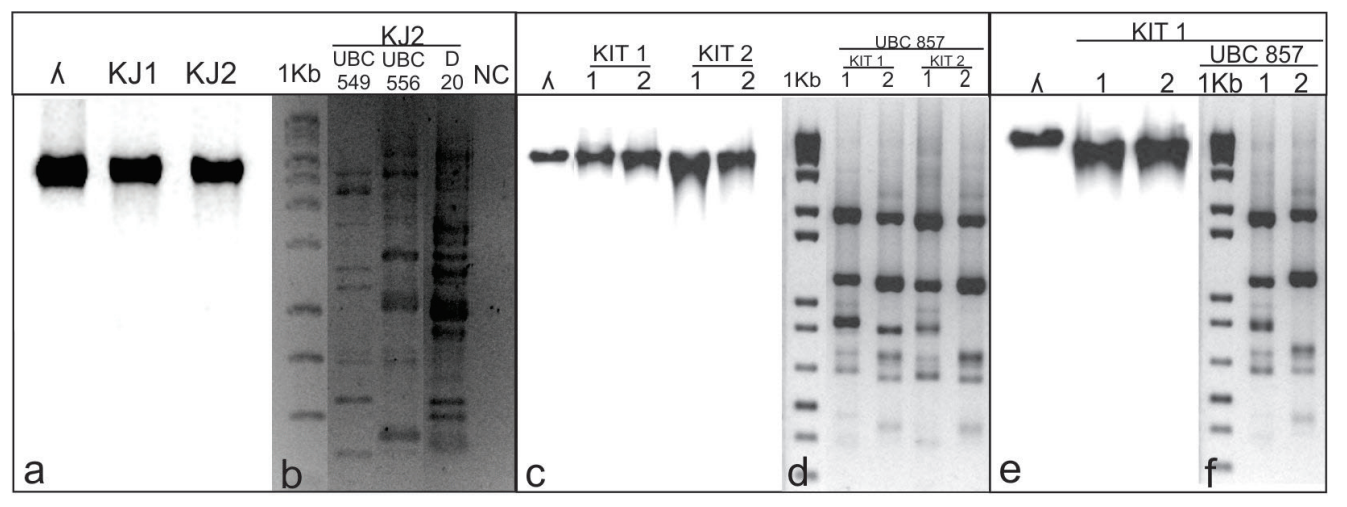

Figure 1. a. Electrophoretic profile of DNA extracted from dehydrated young leaves of mangabeira based on the method described by Khanuja et al. (1999); b. electrophoretic profile of the products of the amplification reactions using the RAPD primers UBC549, UBC556, and D-20, with DNA extracted from dehydrated young leaves of mangabeira and based on the method described by Khanuja et al. (1999); c. electrophoretic profile of DNA extracted from dehydrated young leaves of mangabeira by the two commercial purification kits: kit 1 (Qiagen, Venlo, Netherlands) and kit 2 (Invisorb Spin Plant Mini Kit, Invitek, Berlin, Germany); d. electrophoretic profile of the products of the amplification reactions using the ISSR primer UBC857, with DNA extracted from dehydrated young leaves of mangabeira by kit 1 and kit 2. e. electrophoretic profile of the DNA extracted from fresh young leaves of mangabeira by kit 1 and kit 2 . f. electrophoretic profile of products of the PCR performed using the ISSR primer UBC847 with the DNA extracted from fresh young leaves of mangabeira by kit 1 and kit 2 . phage $\lambda=20$ $\mathrm{ng} / \mu \mathrm{L}$ DNA marker. $\mathrm{NC}=$ negative control.

Genetics and Molecular Research 16 (3): gmr16039724 
Due to the presence of contaminants in the foliar tissues of the species studied that interfere in the DNA isolation process, we tried to optimize the extraction protocols to obtain a large quantity of DNA of good quality. For cell wall disruption and release of cell constituents, in all protocols, except for the two commercial kits, maceration of the leaves was made using liquid nitrogen.

Except for Dellaporta et al. (1983), the other organic protocols utilize CTAB detergent (cetyltrimethylammonium bromide) in the extraction buffer. CTAB solubilizes the membranes and is a cationic surfactant providing a buffer solution for dissociation and selective precipitation of DNA from histone proteins, forming with the DNA a complex that facilitates the DNA precipitation (Allen et al., 2006). There are many DNA extraction protocols that use CTAB due to the composition of cell walls and components of the plant cell (Pervaiz et al., 2011).

The protocol proposed by Ferreira and Grattapaglia (1998) was the only one protocol that included polyvinylpyrrolidone (PVP) in the buffer solution. PVP has antioxidant properties and is responsible for deproteinization and the removal of polyphenols, tannins, and quinone.

The amplification reactions were performed with primers ISSR and RAPD and showed good resolution and band patterning. The DNA was extracted using the two commercial kits and the protocol published by Khanuja et al. (1999) from dehydrated leaves, and using the DNA extraction kit 1 from fresh leaves, indicating that the amount and quality of extracted DNA were sufficient to perform PCR. PCR products can be utilized in molecular studies.

The DNA isolated from fresh leaves by kit 2 was not efficient. Furthermore, the use of a commercial kit for DNA extraction has advantages, including practicality, simplicity, and the lack of acid reagents such as chloroform (Bitencourt et al., 2007; Sousa et al., 2014). However, the main problem with these commercially available kits is their high cost per sample (Ahmed et al., 2009).

The protocol described by Khanuja et al. (1999) is effective for DNA isolation from plant parts with a high amount of secondary metabolites, such as babassu leaves (Viana et al., 2015). Furthermore, it is a low-cost method to isolate high-quality DNA. The method described by Khanuja et al. (1999) using dehydrated leaves of $H$. speciosa stored in a plastic bag containing silica gel generated adequate DNA for experimentation, and it was more efficient than DNA extracted from fresh leaves wrapped in paper towels, kept in plastic bags, and in Styrofoam boxes with ice. The conservation of leaves on silica gel is an alternative for plants located in difficult access regions or collection points far from the place where the extraction of DNA will be performed. Moreover, the use of silica-based extraction protocols helps to preserve DNA and increase the recovery rates of 35-50-bp molecules and can contribute to the sequencing of genomes (Dabney et al., 2013; Meyer et al., 2014).

We recommend the use of the kit 1, kit 2, and the protocol proposed by Khanuja et al. (1999), from dehydrated leaves, and the DNA extraction kit 1 from fresh leaves for DNA extraction from mangabeira in the conditions in which this study was performed. It is important to emphasize that the protocol described by Khanuja et al. (1999), although more laborious, is less expensive than the commercial purification kits tested.

\section{ACKNOWLEDGMENTS}

We are thankful to CNPq (National Counsel of Technological and Scientific Development, Brazil) for financial support and Universidade Federal do Piauí, Teresina, PI, Brazil and EMBRAPA (Meio-Norte), Teresina, PI, Brazil, for the space assigned to perform the experiments.

Genetics and Molecular Research 16 (3): gmr16039724 


\section{REFERENCES}

Ahmed I, Islam M, Arshad W, Mannan A, et al. (2009). High-quality plant DNA extraction for PCR: an easy approach. $J$. Appl. Genet. 50: 105-107. https://doi.org/10.1007/BF03195661

Allen GC, Flores-Vergara MA, Krasynanski S, Kumar S, et al. (2006). A modified protocol for rapid DNA isolation from plant tissues using cetyltrimethylammonium bromide. Nat. Protoc. 1: 2320-2325. https://doi.org/10.1038/ nprot.2006.384

Almeida LM, Floriano JF, Ribeiro TP, Magno LN, et al. (2014). Hancornia speciosa latex for biomedical applications: physical and chemical properties, biocompatibility assessment and angiogenic activity. J. Mater. Sci. Mater. Med. 25: 2153-2162. https://doi.org/10.1007/s10856-014-5255-8

Bitencourt JVT, Roratto PA, Bartholomei-Santos ML and Santos S (2007). Comparison of different methodologies for DNA extraction from Aegla longirostri. Braz. Arch. Biol. Technol. 50: 989-994. https://doi.org/10.1590/S1516$\underline{89132007000700010}$

Campos Filho EM and Sartorelli PAR (2015). Guia de árvores com valor econômico. Agroicone, São Paulo.

Capinan GCS (2007). Seleção de germoplasma de mangabeira (Hancornia speciosa Gomes) definidos por marcadores morfológicos e moleculares. Dissertação (Ciências Agrárias, Área de Concentração: Fitotecnia) - Universidade Federal do Recôncavo da Bahia, Cruz das Almas.

Costa TS, Silva AVC, Lédo AS, Santos ARF, et al. (2011). Diversidade genética de acessos do banco de germoplasma de mangabeira em Sergipe. Pesqui. Agropecu. Bras. 46: 499-507. https://doi.org/10.1590/S0100-204X2011000500007.

Dabney J, Knapp M, Glocke I, Gansauge MT, et al. (2013). Complete mitochondrial genome sequence of a Middle Pleistocene cave bear reconstructed from ultrashort DNA fragments. Proc. Natl. Acad. Sci. USA 110: 15758-15763. https://doi.org/10.1073/pnas.1314445110

Dellaporta SL, Wood J and Hicks JB (1983). A plant minipreparation: version II. Plant Mol. Biol. Report. 1: 19-20. https:// doi.org/10.1007/BF02712670

Doyle JJ and Doyle JL (1987). A rapid DNA isolation procedure for small quantities of fresh leaf tissue. Phytochem. Bull. 19: 11-15.

Ferreira HC, Serra CP, Lemos VS, Braga FC, et al. (2007). Nitric oxide-dependent vasodilatation by ethanolic extract of Hancornia speciosa via phosphatidyl-inositol 3-kinase. J. Ethnopharmacol. 109: 161-164. https://doi.org/10.1016/j. jep.2006.06.009

Ferreira ME and Grattapaglia D (1998). Introdução ao Uso de Marcadores Moleculares em Análise Genética. 3rd edn. Embrapa-Cenargen, Brasília.

Ganga RMD, Ferreira GA, Chaves LJ, Naves RV, et al. (2010). Caracterização de frutos e árvores de populações naturais de Hancornia speciosa Gomes do Cerrado. Rev. Bras. Frutic. 32: 101-113. https://doi.org/10.1590/S0100$\underline{29452010005000019}$

Jimenez HJ, Martins LSS, Montarroyos AVV, Silva Junior JF, et al. (2015). Genetic diversity of the Neotropical tree Hancornia speciosa Gomes in natural populations in Northeastern Brazil. Genet. Mol. Res. 14: 17749-17757. https:// doi.org/10.4238/2015.December.21.48

Khanuja SPS, Shasany AK, Darokar MP and Kumar S (1999). Rapid isolation of DNA from dry and fresh samples of plants producing large amounts of secondary metabolites and essential oils. Plant Mol. Biol. Report. 17: 74-74. https://doi.org/10.1023/A:1007528101452

Lédo AS, Vieira Neto RD, Silva JF, Junior., Silva AVC, et al. (2015). A cultura da mangabeira. Embrapa, Brasília.

Marinho DG, Alviano DS, Matheus ME, Alviano CS, et al. (2011). The latex obtained from Hancornia speciosa Gomes possesses anti-inflammatory activity. J. Ethnopharmacol. 135: 530-537. https://doi.org/10.1016/j.jep.2011.03.059

Meyer M, Fu Q, Aximu-Petri A, Glocke I, et al. (2014). A mitochondrial genome sequence of a hominin from Sima de los Huesos. Nature 505: 403-406. https://doi.org/10.1038/nature12788

Murray MG and Thompson WF (1980). Rapid isolation of high molecular weight plant DNA. Nucleic Acids Res. 8: 43214325. https://doi.org/10.1093/nar/8.19.4321

Nogueira CA, Stafuzza NB, Ribeiro TP, Prado ADL, et al. (2015). Intraspecific differentiation of Hancornia speciosa revealed by simple sequence repeat and random amplified polymorphic DNA markers. Genet. Mol. Res. 14: 1599616005. https://doi.org/10.4238/2015.December.7.12

Oliveira DL (2011). Viabilidade econômica de algumas espécies medicinais nativas do Cerrado. Estudos 38: 301-332.

Pervaiz ZH, Turi NA, Khaliq I, Rabbani MA, et al. (2011). Methodology: a modified method for high-quality DNA extraction for molecular analysis in cereal plants. Genet. Mol. Res. 10: 1669-1673. https://doi.org/10.4238/vol10$\underline{3 g m r 1346}$

Romano E and Brasileiro ACM (1999). Extração de DNA de plantas. Biotecnolog. Cienc. Desenvolv. 5: 40-43.

Genetics and Molecular Research 16 (3): gmr16039724 
Silva GC, Braga FC, Lima MP, Pesquero JL, et al. (2011). Hancornia speciosa Gomes induces hypotensive effect through inhibition of ACE and increase on NO. J. Ethnopharmacol. 137: 709-713. https://doi.org/10.1016/j.jep.2011.06.031

Soares ANR, Melo MFV, Vitória MF and Silva AVC (2015). Physiological quality of mangabeira seeds submitted to drying. Afr. J. Agric. Res. 10: 4808-4813.

Sousa CC, Gomes SO, Lopes ACA, Gomes RL, et al. (2014). Comparison of methods to isolate DNA from Caesalpinia ferrea. Genet. Mol. Res. 13: 4486-4493. https://doi.org/10.4238/2014.June.16.7

Viana JPG, Borges ANC, Lopes ACA, Gomes RL, et al. (2015). Comparison of eight methods of genomic DNA extraction from babassu. Genet. Mol. Res. 14: 18003-18008. https://doi.org/10.4238/2015.December.22.26

Genetics and Molecular Research 16 (3): gmr16039724 